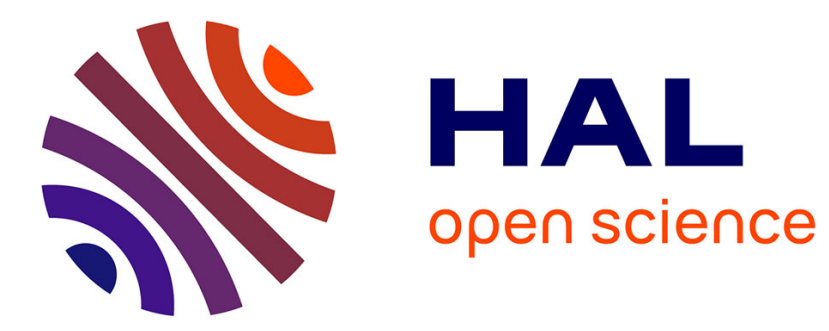

\title{
Systematics of the Dioryctria abietella species group (Lepidoptera: Pyralidae) based on mitochondrial DNA
}

Géraldine Roux-Morabito, Nancy Gillette, Alain Roques, Laurent Dormont, John Stein, Felix Sperling

\section{- To cite this version:}

Géraldine Roux-Morabito, Nancy Gillette, Alain Roques, Laurent Dormont, John Stein, et al.. Systematics of the Dioryctria abietella species group (Lepidoptera: Pyralidae) based on mitochondrial DNA. Annals of the Entomological Society of America, 2008, 101 (5), pp.845-859. 10.1093/aesa/101.5.845. hal-02659519

\section{HAL Id: hal-02659519 \\ https://hal.inrae.fr/hal-02659519}

Submitted on 30 May 2020

HAL is a multi-disciplinary open access archive for the deposit and dissemination of scientific research documents, whether they are published or not. The documents may come from teaching and research institutions in France or abroad, or from public or private research centers.
L'archive ouverte pluridisciplinaire HAL, est destinée au dépôt et à la diffusion de documents scientifiques de niveau recherche, publiés ou non, émanant des établissements d'enseignement et de recherche français ou étrangers, des laboratoires publics ou privés. 
Version définitive du manuscrit publié dans / Final version of the manuscript published in : Annals of the Entomological Society of America. 2008, 101(5), 845-859

Systematics of the Dioryctria abietella species group (Lepidoptera: Pyralidae) based on mitochondrial DNA.

G. ROUX-MORABITO ${ }^{1}$, N. E. GILLETTE ${ }^{2}$, A. ROQUES ${ }^{1}$, L. DORMONT ${ }^{3}$, J. STEIN $^{4}$ and F. A. H. SPERLING ${ }^{5}$

\footnotetext{
${ }^{1}$ INRA, Centre d’Orléans, Unité de Zoologie Forestière, BP20619 Ardon, 45166 Olivet cedx, France

${ }^{2}$ Pacific Southwest Research Station, USDA-Forest Service, Albany, CA 94710

${ }^{3}$ Centre d'Ecologie Fonctionnelle et Evolutive, CNRS UMR 5175, 1919 Route de Mende, 34293 Montpellier Cedex 5, France

${ }^{4}$ Forest Health Technology Enterprise Team, USDA-Forest Service, Morgantown, WV 26505

${ }^{5}$ Department Biological Sciences, University of Alberta, Edmonton, AB T6G 2E9, Canada
}

Corresponding author : Géraldine ROUX-MORABITO

INRA, Centre d’Orléans, Unité de Zoologie Forestière, BP20619 Ardon, 45166 Olivet cedx, France

Phone +33(0)238418033

Fax +33 (0)238417879

geraldine.roux-morabito@ orleans.inra.fr 


\begin{abstract}
Coneworms of the genus Dioryctria Zeller include a number of serious pests of conifer seeds that are notoriously difficult to distinguish as species. We surveyed mitochondrial DNA variation within the abietella species group by sequencing 451 bp of COI and 572 bp of COII genes from 64 individuals of 6 major species in the group. In addition to examining phylogenetic relationships within European members of the group, the study focused on the two most damaging species, D. abietivorella Grote from North America and D. abietella Denis and Schiffermüller from Europe and Asia, which have been considered taxonomically synonymous in the past. In order to detect different levels of divergence, we extensively sampled in seed orchards and natural forests for D. abietella on different hosts. Maximum parsimony and maximum likelihood analyses confirmed the monophyly of the abietella species group and its separation into three clades. The grouping of North American species (Clade A) received strong support in both analyses, whereas relationships between Clade A and the two other European clades were weakly supported. D. simplicella Heinemann could not be unambiguously separated from $D$. abietella populations. The diverse haplotypes observed in the network analysis conducted with eight populations of polyphagous $D$. abietella suggested the presence of two distinct lineages in France.
\end{abstract}

\title{
Key words
}

Dioryctria, mtDNA, COI, COII, seed orchard 


\section{Introduction}

The greater diversity of phytophagous insect clades compared to their

nonphytophagous sister groups has lead biologists to postulate that host plants strongly influence the diversification and speciation of herbivorous insects (Kelley et al. 1999). Two patterns of association between phytophagous insects and their host plants exist, with some species using a diversity of host taxa (polyphagy), and others being restricted to one particular plant species (monophagy). According to numerous authors (Bush 1975, Mitter and Futuyma 1979, Diehl and Bush 1984, Tauber and Tauber 1989, Dres and Mallet 2002, Rundle and Nosil 2005), changes in host preference can be critical to the formation of new species. Such genetic differentiation has been associated with host use in several polyphagous species, which frequently consist of locally specialized populations, races or even sibling species complexes (Menken 1996). Lepidoptera include numerous examples of species complexes in which there are evolutionarily significant entities that may or may not represent species (Sperling 2003, Wahlberg et al. 2003). Because morphological characters of such related species or subspecies are very hard to distinguish, their autecology and host plants are often used for taxonomic identification, but the use of such labile characters raises doubts about the validity of the taxonomic status of these taxa.

Coneworms of the genus Dioryctria Zeller (Lepidoptera: Pyralidae) comprise several species groups within which numerous species have been identified mainly on the basis of their larval host-plant, but also by forewing morphology and geography (Neunzig 2003). These coneworms are serious pests of conifer seed cones in the Holarctic region (Turgeon et al. 1994), where over 70 species have been recorded (Du et al. 2005, Roe et al. 2006). Most of them are associated with the Pinaceae, especially with Pinus Linnaeus, Picea A. Dietrich, Abies Miller, Larix Miller, and Pseudotsuga Carrière species (Hedlin et al. 1980, Roques 1983, Cibrian-Tovar et al. 1986, Neunzig 1990, Turgeon and deGroot 1992), with a few 
being observed on Taxodiaceae (Merkel 1984). Because these species may drastically limit crops of genetically superior seeds in seed orchards, their biology has been studied extensively during the past forty years (Lyons 1957, Zocchi 1961, Neunzig et al. 1964, Charles and Roques 1977, Grant et al. 1993, Millar et al. 2005).

However, a paucity of clear morphological characters for separating Dioryctria taxa creates taxonomic uncertainties that hinder the analysis of their host relationships (Chatelain and Goyer 1980, Hedlin et al. 1980, Sopow et al. 1996). Using a combination of external characters and adult genitalia, Mutuura and Munroe (1972) defined seven species groups but could not definitively place all the studied species into groups (Du et al. 2005). Among these groups, the abietella species group comprises 13 species and is defined by the absence of raised scales on the forewings, a feather- like maxillary palpus in the male, and a narrow valva in the male genitalia. According to Mutuura and Munroe $(1972,1973)$ and Neunzig (2003), this group includes the widespread Palaearctic species D. abietella Denis and Schiffermüller, and species from Europe (D. pineae Staudinger, D. mendacella Staudinger, D. simplicella Heinemann= D. mutatella Fuchs; Fazekas, 2002), North Africa (D. alloi Barbey, D. peyerimhoffi Joannis), Asia (D. stenopterella Amsel, D. assamensis Mutuura, D. raoi Mutuura), North America (D. abietivorella Grote, D. ebeli Mutuura and Munroe, D. pinicolella Amsel), and Central America (D. sysstratiotes Dyar).

Dioryctria abietella and D. abietivorella are undoubtedly the most important lepidopteran pests of conifer cones in Europe and North America (Roques, 1983, Hedlin et al., 1980). They both have a wide host-range for larval development. So far, D. abietella has been recorded from western Europe and Scandinavia to the Russian Far East and northern China on a broad range of hosts, including cones of pine, spruce, larch, fir and Douglas fir, and more rarely twigs, buds, and adelgid-induced galls (Roques 1983). D. abietivorella has been reported from Alaska to central Mexico, and from California to Newfoundland, on more 
than 20 different hosts, including pine, spruce, and Douglas fir (Lyons 1957, Hedlin et al 1980, Turgeon and de Groot 1992). Because these two species are generally similar in genital characters, they have variously been considered under the names D. abietella, D. assamensis and D. raoi (Munroe 1959, Byun et al. 1998).

More recently, there has been similar confusion among European Dioryctria species such as $D$. abietella, D. simplicella, and even species outside the abietella group such as $D$. schuetzeella Fuchs (Charles and Roques 1977, Roques 1983). For example, D. resiniphila Segerer and Pröse was recently identified in cones of Abies cephalonica (Segerer and Pröse, 1997) in Greece, but in the past these coneworms had been identified as D. abietella. Species-specific treatments such as semiochemicals (DeBarr et al. 2000) or pathogens (Verma et al. 1996, Perez et al. 1999, Glynn and Weslien 2004) are frequently required for the control of such cryptic pests, which are not amenable to control using pesticides without resorting to highly toxic organophosphate and carbamate insecticides (Bhandari et al. 2003) or multiple injections of systemic insecticides (Grossman et al. 2002). The success of such species-specific treatments relies upon correct pest species diagnoses. Thus, it is important to focus on clarifying the status of taxonomically intractable taxa like Dioryctria species groups, so that effective control measures can be tailored to each species.

In taxonomic groups where morphological identification is difficult, molecular characters, particularly mtDNA, can help in assessing species boundaries (Sperling and Hickey 1994, Brower 1999, Caterino et al. 2000, Templeton 2001, Kerdelhué and Rasplus 2002, Hebert et al. 2003a, Wahlberg et al. 2003, Roe and Sperling 2007b). Several properties make mtDNA a good marker of species limits (Avise 1991, Sperling 2003, Wahlberg et al. 2003). It is a non-recombining, maternally inherited genome, with a smaller effective population size that leads to shorter coalescence times (Moore 1995). Moreover, gene trees may be more likely to reflect species trees when using mitochondrial markers (Avise 2000, 
Sperling 2003). Thus, the rapid evolution of mtDNA sequences has often been used in intraspecific studies (Avise 2000) as well as in investigating relationships of closely related species in Lepidoptera (Bogdanowicz et al. 1993, Brower and DeSalle 1994, Brower 1999; Brown et al. 1994, Sperling and Hickey 1994, Sperling et al. 1995, Landry et al. 1999, Kruse and Sperling 2001, Sperling 2003, Wahlberg et al. 2003, Du et al. 2005, Roe and Sperling 2007a, 2007b). So far no molecular study has been performed across the widespread and economically important European D. abietella coneworm group; and genetic and biochemical analyses of Dioryctria have so far been primarily limited to North American and Chinese species (Richmond and Page 1995, Du et al. 2005, Roe et al. 2006).

In this paper we review species delimitations and phylogenetic relationships within the Dioryctria abietella species group based on mtDNA sequences. We give special emphasis to the taxonomic status of the two most damaging Dioryctria species of this group, namely European D. abietella and North American D. abietivorella.

\section{Materials and methods}

\section{Coneworm collections}

A total of 67 specimens were selected for this study, 61 within the Dioryctria abietella species group (29 specimens identified as D. abietella, nine D. mendacella, two D. pineae, eight D. simplicella, 11 D. abietivorella and two D. ebeli) and six additional specimens representative of three other Dioryctria species groups (two specimens of the pine stem borer D. sylvestrella Rartzeburg belonging to the sylvestrella group, two specimens of $D$. amatella Hulst belonging to the zimmermani group, one specimen of D. pseudotsugella Munroe and one of $D$. reniculelloides Mutuura and Munroe belonging to the schuetzeella group). The list of corresponding larval hosts and locations is presented in Table 1. In order to ascertain insect-host relationships, only insects reared from identified host cones were considered. We 
carried out most sampling, but some specimens were provided by collaborators. In addition, three published sequences were incorporated in order to relate our study to previous publications (Table 1). These included one D. abietella from China (Du et al. 2005), and two D. abietivorella from Chico, California (Roe et al. 2006).

Sampling of D. abietella was designed to survey different potential levels of divergence. Populations were defined according to the larval host tree and collecting localities. Thus, sympatric populations of $D$. abietella developing simultaneously on different hosts were sampled on three locations in France (Fig.1): (i) in a natural forest with mixed Pinus cembra (Linnaeus) and Picea abies (Linnaeus) in the northern Alps; (ii) in a seed orchard that included the native species Picea abies and Larix decidua (Miller), and the exotic species Pseudotsuga menziesii (Mirbel) Franco at Latronquière (south-central France); and (iii) in an arboretum that included, among other species, the exotic species Picea smithiana (Wall.) and Pinus koraiensis Linnaeus) (Les Barres, northern-central France). No natural forests surrounded the Latronquière seed orchard.

Dioryctria larvae were extracted from damaged cones, and either reared until adult emergence or killed immediately in $95 \%$ ethanol and kept at $-80^{\circ} \mathrm{C}$ until DNA extraction. Adults were identified using morphological descriptions from Zocchi (1961) and Mutuura and Munroe (1972, 1973), or on the basis of the larval host (Charles and Roques 1977) when morphological identification was uncertain and compared with adult DNA from the same species (four larval specimens were identified as D. mendacella and five larvae identified as D. simplicella).

\section{DNA protocols}

The methods used for DNA extraction, amplification using the polymerase chain reaction (PCR), and sequencing follow Sperling et al. (1994). Genomic DNA was extracted 
from the thorax of both larvae and adults. The remaining body parts, including head, legs, wings and abdomen were stored at $-80^{\circ}$ and retained as vouchers at the University of Orleans. Specimens were vacuum-dried to remove ethanol before extraction. DNA was purified using a phenol/chloroform based extraction and eluted in $200 \mu \mathrm{l}$ of LTE buffer.

One microliter of extracted DNA was used as template for amplification of mtDNA fragments by PCR following methods primarily developed for spruce budworm (Sperling and Hickey 1994). Using Promega Taq, 30 cycles of amplification were performed as follows in $50 \mu \mathrm{l}$ reaction volumes: denaturation step at $94^{\circ} \mathrm{C}$ for $1 \mathrm{~min}$, annealing step at $45^{\circ} \mathrm{C}$ for 1 min, and extension step at $72^{\circ} \mathrm{C}$ for $1 \mathrm{~min} 30 \mathrm{sec}$. An initial cycle employed a 3 min denaturation at $95^{\circ} \mathrm{C}$ and a final cycle had an extension step of $72^{\circ} \mathrm{C}$ for $5 \mathrm{~min}$.

Overlapping sections of a 2272-bp region of one individual of each of Dioryctria abietivorella and D. reniculelloides, and 1975-bp for two specimens of D. abietella that are respectively homologous to bases 1457-3729 and 1754-3729 in Drosophila yakuba Burla (Clary and Wolstenholme, 1985) were PCR-amplified using heterologous primers (list in Table 2). This region includes the gene coding for the cytochrome oxidase subunit 1 (COI), and extends through the tRNA leucine gene, and ends in the cytochrome oxidase subunit 2 gene (COII). An additional 60 samples, representing one to five specimens per population, were sequenced over 451 bp of COI (primers $N^{\circ} 4,7$ ) and 572 bp of COII (primers $\mathrm{N}^{\circ} 10,12$ ). Both strands of the PCR product were sequenced for all samples. Fragments were sequenced directly using Big Dye Terminator (Applied Biosystems) and detected with an ABI 377 automatic sequencer (Applied Biosystems, Foster City, CA).

\section{Data analysis}

DNA contigs were constructed using Sequence Navigator (Applied Biosystems) and aligned manually with published sequences of Dioryctria abietella from China and $D$. 
abietivorella from USA (Du et al. 2005, Roe et al. 2006). Sequences of two species in the Phycitini, Oncocera faecela and Ceroprepes ophthalmicella (Du et al. 2005) were used as outgroups to root Dioryctria.

Maximum parsimony (MP) and maximum-likelihood (ML) phylogenetic analysis were performed with PAUP*4b10 (Swofford 2002). For maximum parsimony analysis, a heuristic search was implemented with the tree bisection-reconnection (TBR) branchswapping option. Variable nucleotide positions were treated as unordered characters with one state for each nucleotide base. The relative level of support for each phylogenetic grouping was assessed with the bootstrap method (Felsenstein 1985). For analysis, MODELTEST v3.07 (Posada and Crandall 1998) was used to determine the model of evolution across the COI and the COII genes. To test for homogeneity of our data set, we used a partition homogeneity test (ILD) for detecting incongruence caused by differences in evolutionary constraints and/or tree topologies (Farris et al. 1994). We performed the ILD test in PAUP using heuristic searches with tree bisection-reconnection (TBR) branch swapping, and 100 random taxon addition replicates.

Sequence divergences were calculated using uncorrected pairwise distances with PAUP. A statistical parsimony network was constructed with D. abietella haplotypes using TCS version 1.21 (Clement et al. 2000).

Genetic structure within and among European D. abietella populations was examined by Analysis of Molecular Variance (AMOVA) (Excoffier et al. 1992) as implemented in ARLEQUIN version 3.0. Populations were grouped either by geographical location (region) or by host species or by host origin (see Fig. 1 and Table 4 for details). Levels of significance were determined through 1000 random permutation replicates.

\section{Results}




\section{Sequence selection}

Sequence was obtained for the full 2272 bp region (including the COI+tRNAleu+COII genes) in one D. abietivorella specimen (GenBank accession number EU407773). For two specimens of D. abietella a fragment of 1975 bp (start of COI missing) was obtained (GenBank number EU407772). Overall sequence divergence between these two species was estimated at 3,7\% (73 substitutions, 51 in COI and 22 in COII), based on the 1975 bp region. Ten of the variable sites showed transversions (8 in COI and 2 in COII). There was variation in amino acids at 4 locations in COI and COII. No insertion or deletion of sequence was observed between the two species. On the basis of variation observed in these longer sequences, as well as the relative effectiveness of different primer combinations, two shorter regions were chosen to survey mitochondrial sequence variation for the remainder of the study.

Fifteen haplotypes were found among the 29 D. abietella specimens, five haplotypes among the eleven $D$. abietivorella specimens, five haplotypes among the nine $D$. mendacella and two haplotypes among the eight $D$. simplicella. Divergences within and between lineages (species) and species groups of Dioryctria were compared between the 451-bp COI versus the 572-bp COII fragments and across the 2 combined gene fragments (Table 3 and Appendix for complete data of pairwise divergences). For all data sets (COI, COII, COI+COII), maximum divergence between lineages did not overlap minimum divergence between species group, and uncorrected pairwise distances were comparable to divergences already reported in the genus Dioryctria by Roe and Sperling (2007a, 2007b) and Du et al. (2005). By contrast, intraspecific divergence in D. abietella (within lineages) exceeded the interspecific divergence between sister pairs of the abietella species group for two data sets (maximum 0.035 in D. abietella versus minimum 0.014 in abietella species group and maximum 0.023 versus minimum 0.011 for COII and COI+COII respectively). Moreover, 
when sequence divergence was compared within D. abietella, mean pairwise distances differed substantially between the two genes (0.002 in COI versus 0.018 in COII), the number of variable nucleotide sites being five times less in COI (4 transitions with 1-0-3 changes at first, second and third codon positions, respectively) than in COII (18 transitions and 2 transversions with 2-1-17 changes at first, second and third codon positions, respectively). There were three amino acid replacements within the COII gene, including one valine versus isoleucine (bp 506), one phenylalanine versus leucine (bp 518), and one phenylalanine versus serine (bp 952). No ambiguous site (double peak) was detected. When compared between species belonging to abietella species group, mean pairwise distances were similar (0.027 in COI versus 0.029 in COII). Mean pairwise comparisons between the two species D. abietivorella and D. abietella were higher in the COI fragment gene (0.041) versus in the COII gene (0.034). To minimize the great variability detected in intraspecific divergence rate between the COI fragment gene and the COII gene and to minimize the stochastic variation across taxa, we used the combined sequence because this gave a better average of overall divergence rates across COI and COII.

The ILD test between full length sequences of COI and COII genes revealed no significant conflict $(\mathrm{P}=0.13)$. Modeltest was applied to determine the most appropriate model of sequence evolution. The general time reversible model with the following base composition ( $A=0,33290 ; C=0,10870 ; G=0,12960 ; T=0,42880$ ), rate of invariable sites (0.6068), and gamma distribution (0.6041) $(\mathrm{GTR}+\mathrm{I}+\mathrm{G}$, Tavaré 1986) was the substitution model selected for the combined COI+COII data set. 


\section{Phylogenetic reconstruction}

One sequence for each combination of haplotype, host and locality was retained for phylogenetic reconstruction. The consensus of 3 most parsimonious (MP) trees (CI=0.572; $\mathrm{RI}=0.863$; excluding uninformative characters) and the maximum likelihood (ML) tree, using 451 bp in COI and 572 bp in COII, are shown in Fig. 2. The monophyly of the abietella species group relative to species in the three other Dioryctria groups is strongly supported by MP analysis but weakly by ML analysis (100\% and 56\% bootstrap values respectively). The monophyly of the genus Dioryctria relative to the two outgroup species in other Phycitini genera was supported by 79\% in MP and 72\% in ML analysis.

When the MP and ML phylogenetic reconstructions were compared, there were some differences at the ingroup level. The most conspicuous difference was the position of the North American species relative to European ones. The Dioryctria abietella species group was separated into three major clades (A, B and C). Clade A contained all specimens from North America, D. abietivorella and D. ebeli. According to both MP and ML analyses this first clade was clearly separated from European and Chinese specimens (100\% and 96\% bootstrap support). Clades B and C were weakly supported by both analyses (bootstrap values comprised between 52 to 75\%). Clade B mainly consisted of D. abietella haplotypes plus the $D$. simplicella haplotypes. The abt12 haplotype, corresponding to three D. abietella specimens collected at Latronquière on Douglas fir and at Les Barres Arboretum on Picea smithiana, formed a clade with specimens of D. simplicella collected in Fontainebleau and in Poland on Pinus sylvestris. The pairwise distance between abt12 and D. simplicella was 1.2\%, whereas distances between abt12 and other D. abietella haplotypes ranged between 1.6 to $3.8 \%$ for haplotypes from same localities. Clade C grouped together specimens of $D$. mendacella and $D$ pineae, all of which were collected on the Mediterranean pines $P$. halepensis and P. pinae. This clade had a basal trichotomy of three haplotype lineages that 
were separated by $1.4-1.5 \%$ from each other. One of the lineages (pin1) represented $D$. pineae, and the two others (mend $1+2+3$ and mend $4+5$ ) were identified as $D$. mendacella, indicating uncertainty in the phylogenetic relationships of these two species.

The European pine stem borer D. sylvestrella (sylvestrella species group) was clearly separated from the abietella group and clustered with specimens of D. amatella (zimmermani species group). The specimen of the North American species D. pseudotsugella formed a well supported monophyletic group with the specimen of $D$. reniculelloides, supporting the placement of both species in a separate species group.

\section{Dioryctria abietella haplotype network}

Thirteen mitochondrial haplotypes were detected among the $30 \mathrm{D}$. abietella specimens analysed. Interestingly, most of the haplotype diversity was distributed in artificial stands in France (Fig. 1 and Table 1). Of the eleven specimens from natural stands in the French and Italian Alps, ten had the abt1 haplotype, regardless of host and locality. This major haplotype (abt 1) was also present in an artificial stand in the Latronquière seed orchard, on three different hosts (Picea abies, Pseudotsuga menziesii and Larix decidua). Seven other unique haplotypes (abt3, abt5-9 and abt11) were found in this locality, plus one divergent haplotype (abt12) shared with the Picea smithiana population from Les Barres Arboretum. Three remaining haplotypes were also found in Les Barres (abt4 on Picea smithiana, abt11 on Pinus koraiensis and abt10 on both species). Haplotypes from China (abt13) clustered with the major haplotype abt1.

The hostplant association and phylogenetic relationships of all haplotypes in $D$. abietella are summarized in a network (Fig. 3), based on COI and COII sequences. This network revealed two haplotype groups separated by seven mutational steps. One comprised all 11 individuals from natural forests in the Alps (abt1, abt2) plus Chinese sequence, 
separated by five mutational steps from three individuals from the Latronquière seed orchard and Les Barres Arboretum (abt3, abt4). The second group, more polymorphic, comprised only individuals from artificial stands (arboretum and seed orchard, abt5, 6, 8 to 11), with the exception of one haplotype (abt7) displayed by one individual on Larix decidua from the Latronquière seed orchard. The three individuals that had the abt12 haplotype were well separated from the other Dioryctria haplotypes and was not be included in the haplotype network produced by TCS.

\section{Genetic structure of D. abietella populations}

The results of the AMOVA analyses performed in D. abietella are presented in Table 4. When populations were grouped by geographic region (Alps, Central France and South Western France) (see Fig. 1), genetic variation was partitioned half between regions (51.08\%) and half within each population (48.92\%), this result being significant. When populations were grouped by host plant, $58 \%$ of the genetic variation was found within populations, $40 \%$ between populations within hosts and $2 \%$ between hosts. Only genetic variation within populations was significant. When populations were grouped by type of stand, $55.6 \%$ of the genetic variation was significantly found between groups, i.e. natural forest versus artificial stands, variation within population being also significant.

\section{Discussion}

\section{Sequence divergence in COI versus COII}

Although mtDNA genes have long dominated the field of molecular systematics, gene choice and fragment length are crucial when inferring phylogenetic relationship between species. The COI+COII gene region has frequently been sequenced in Lepidoptera (Sperling 
2003) and a recent review (Roe and Sperling 2007a) examined patterns of evolution of these two mitochondrial genes and ramifications for delineating species boundaries in Lepidoptera and Diptera. They demonstrated that DNA substitution patterns can vary between independent lineages and change as taxa become increasingly diverged (see also Galtier et al. 2006). Nevertheless, studies of intraspecific patterns of divergence are performed with a limited number of conspecific populations (Wahlberg et al. 2003, Roe and Sperling 2007a). Better sampling throughout the geographic range of the species should maximize sampling of mtDNA haplotype diversity and consequently minimize the effect of localized stochastic mutational anomalies.

Our study provides an opportunity to evaluate the variability of divergence rates between COI and COII in a species group with sequence available at different taxonomic levels (populations, sister species and species groups). The high variability observed in intraspecific divergence rate (five times more in COII than in COI within Dioryctria abietella) was unexpected and contrasts with the interspecific divergence rates in Dioryctria demonstrated by Roe and Sperling (2007a). We ruled out technical artifacts due to DNA contamination or PCR-sequencing errors. However, extreme sequence divergence in COII could reflect the presence of nuclear copies of mitochondrial DNA (numts) that had contaminated sequences of $D$. abietella. Nevertheless, there were neither ambiguous polymorphic sites, nor unexpected stop codons in any of the sequences analysed, nor elevated numbers of amino acid changes. Numts have been more commonly found in plants than in animals and few studies have been reported in insects (Bensasson et al.2001, Keller et 2007). The presence of numts was also inferred but not proven in tropical Lepidoptera by Hajibabaei et al. (2006). Similar divergence variability between COI and COII was also observed within the longhorn beetle Monochamus galloprovincialis, in which numerous numts have been detected (Koutroumpa et al. 2008). 
Roe and Sperling (2007a) found that maximum intraspecific diversity in Lepidoptera, including Dioryctria pentictonella,was usually found in COI. Although such patterns of sequence variation may be due to random stochastic variability, they may also suggest that the common assumption of neutral molecular evolution in mtDNA is not justified. Non random regional variation has previously been shown to occur in mtDNA (Broughton and Reneau 2006, Galtier et al. 2006) and several factors such as functional constraints, mutation hot spots, or adaptive substitutions could explain heterogeneous evolutionary rates observed in Dioryctria (Lunt et al. 1996, Stoneking 2000, Innan and Nordborg 2002).

Our study highlights the importance of considering other genes than COI, such as COII, as well as independent markers as nuclear markers, when studying phylogenetic relationships between closely related species, especially if they display high genetic diversity or low interspecific divergence. In this context, it is reasonable to ask whether the COII gene is optimally informative by itself for reconstructing phylogenetic relationships of closely related species. Short fragments have commonly been used to identify sister species, especially for DNA barcoding (Hebert et al. 2003a). However, such reliance on short fragments has been controversial (Wahlberg et al. 2003, Roe et al. 2006), especially when only a single specimen is used to define a lineage. Roe and Sperling (2007a), argued that it may be advantageous to focus on regions that give accurate and consistent estimates of divergences relative to longer mtDNA regions. They identified a 600-bp fragment as the best indicator of total COI-COII divergence (mean percent divergence of $100.7 \%$ relative to total COI-COII divergence) for sister species in Lepidoptera and Diptera. The COI gene fragment used in our study partially spanned this region, and showed overall interspecific and intraspecific pairwise divergences similar to other Lepidoptera (Wahlberg et al. 2003, Blum et al. 2003, Du et al. 2005) (0-0.011). In contrast, the COII gene showed lower minimum interspecific divergence (0.14) and higher maximum intraspecific divergence (0.35) 
compared to distances previously recorded in Dioryctria species (Du et al. 2006, Roe et al. 2006).

When separate data sets (COI or COII) for phylogenetic reconstructions of Dioryctria species group were compared, COI gave a more accurate indication of species boundaries than COII (data not shown), all haplotypes being grouped according to their respective taxon relationship in COI, whereas the COII gene separated $D$. abietella into two clades. Incongruences between species trees and mtDNA trees have often been reported in closely related taxa (Avise 1991, Funk and Omland 2003, Ballard and Whitlock 2004). Thus reliance on a single DNA region can be misleading, in part due to underestimates or overestimates of sequence divergence between taxa, particularly between sister pairs.

\section{Intraspecific variability of the polyphagous European Dioryctria abietella:}

Although short fragments of COI have commonly been used to identify closely related species in Lepidoptera (Caterino et al. 2000) and for DNA barcoding (Hebert et al. 2003b), the combination of more than one DNA region (or longer DNA fragments) to identify closely related species or to distinguish populations is strongly supported (Wahlberg et al. 2003, Roe et al. 2006). In addition to the fact that most D. abietella populations in our study contained at least three specimens, the combination of two mtDNA fragments showing contrasting evolutionary rates, targeting a region of maximum divergence (COII gene which was more divergent than COI in this species), should improved resolution considerably in intraspecific analysis.

Analysis of molecular variance within $D$. abietella did not show any clear genetic differentiation among hosts (Table 4), even if most variation in the plains haplotypes was restricted to single host species (see Fig. 1 and Table 1). Dioryctria abietella is unusual among the European members of its group in that it is relatively polyphagous, feeding on 
hostplant species from a number of unrelated coniferous genera. According to numerous authors (Johnson et al. 1996, Funk and Omland 2003, Rundle and Nosil 2005), divergent habitat preferences are more likely to cause prezygotic isolation when mating occurs in or near the preferred habitat, for example between herbivorous insect populations that mate on the plant on which they feed. But according to Emelianov et al. 2001, mating behavior in many plant-feeding insects does not depend directly on host cues. Hence, in most Lepidoptera, the host plant is not required for mating, and females call for males using longrange pheromones. Because of its polyphagy, D. abietella populations are less likely to experience disruptive selection following shifts to novel host plants (Mopper and Strauss 1998, Berlocher and Feder 2002, Funk and Omland 2002). Furthermore, our sampling was performed on numerous exotic conifer trees that may not represent of the natural host range of the species. Additional studies of the ecology and genetics of this species are needed to investigate further insect-host relationships.

Results of the AMOVA revealed the presence of significant population structure, showing that $51 \%$ of the variation was due to the subdivision of populations by geographic origin (Table 4). This result was mainly due to the strong divergence of populations from the plains, fixed for a number of unique singleton haplotypes, compared to populations from the Alps that displayed the widespread haplotype abt1 and only one singleton (abt2). Furthermore, when populations are grouped by origin of stand (native forest vs. artificial plantation), the percentage of variance accounted for is higher (56\%), which is more indicative of geographic distribution of the stand than of the type of the stand (i.e. native forests in Alps versus artificial plantations in plains localities, and Latronquière seed orchard versus Les Barres Arboretum).

Distinct selection pressures could play a role in the difference between genetic diversity in populations from the Alps and those in the plains. For most insects that are 
specific to cones, annual fluctuations in resource availability are a major driving force governing their population dynamics (Turgeon et al. 1994). In the natural forests of the Alps, it is likely that coneworm populations have evolved together with the hosts and adapted to masting; i.e., substantial annual fluctuations in cone abundance. In contrast, the plain populations, and especially those developing within the Latronquière seed orchard, faced only limited fluctuations in annual cone crop because the orchard trees were submitted to treatments to promote annual flowering. So diet breadth might be an important parameter in the observed genetic patterns, as can be observed in other forest insects (Kerdelué et al. 2002), and the low genetic variability observed in the Alps could be due to more episodic cone production than populations from the plains. However, we cannot rule out the hypothesis that past climatic oscillations during the Quaternary period may have affected the patterns of genetic diversity of D. abietella (Hewitt 1996). The low genetic diversity in present-day populations from the natural forest in the Alps could be attributable to a single mountain refugium, whereas the high genetic diversity in introduced areas could result from multiple origins from different refugial sources during the ice ages or, more likely, from movements of insects due to transportation of cones into these areas. It would be useful to conduct a more comprehensive phylogeographic study on this palearctic species.

The unexpected discovery of two distinct groups of D. abietella haplotypes, which was particularly evident in the haplotype network (Fig. 3), may indicate the presence of at least two diverged lineages within the species $D$. abietella. The widespread abt1 haplotype found mainly in the Alps and in some plains localities is very close to the Chinese haplotype, and is therefore most likely to represent the specimens originally described as $D$. abietella from the vicinity of Vienna (Wienergegend) in Austria (Denis and Schiffermüller 1776). The second haplotype group appeared to be much more difficult to define without further exploration. However, even species placed in different species groups may be difficult to 
distinguish. For example damage from the trunk borer $D$. splendidella (Jactel et al. 1994) has long been confused with that of $D$. abietella in France or $D$. schuetzeella, since it is also known to attack cones of Picea abies in Europe (Schwenke 1982). Nonetheless, we did not observe specimens that were morphologically diagnosable to $D$. splendidella or $D$. schuetzeella in our surveys, nor did we find any haplotypes similar to the D. schuetzeella mtDNA (Knölke et al. 2005). The recently identified D. resiniphila (Segerer and Pröse 1997) will also need to be considered in further analyses.

\section{Molecular systematics of the abietella species group}

Our results from mtDNA sequence variation among species are congruent with the findings of Du et al. (2005) and Roe et al. (2006), with D. abietivorella and D. abietella supported as a separate species. The results confirm the original diagnosis of Munroe (1959) who separated D. abietella from D. abietivorella using external and internal morphological criteria, including larger size, darker hind wings, more conspicuous pale markings, more transverse dark lines on forewings, and a different configuration of the male valva in $D$. abietella. Numerous other studies have advocated the use of mtDNA sequences as a valuable marker for identifying closely related species, especially where morphological differences are subtle, in some cases confirming and in others refuting previous interpretations (e.g. Sperling and Hickey 1994, Sperling et al. 1995, Caterino and Sperling 1999, Cognato et al. 1999, Kerdelhué et al. 2002, Kruse and Sperling 2001, Wahlberg et al. 2003, Damgaard and Cognato 2006).

The topology of the phylogenetic reconstruction shown in Fig. 2 reveals the monophyly of the abietella group and its separation from members of the three other Dioryctria groups (sylvestrella, schuetzella and zimmermani) as defined by Mutuura and Munroe (1972) and Neunzig (2003). When considering the mitochondrial data set, within- 
species group genetic distances (1.1-4.5\%) were always lower than between-species group pairwise distances (5.7-8.6\%). A recent study of the same genus showed similar results but more overlap, with sequence divergence ranging from $0.3 \%$ to $5.6 \%$ among species within groups and 3.3\% to 9.2\% among species in different groups (Du et al. 2005). Low rates of overlap in mtDNA genetic distances within and between species have been found in other Lepidoptera. In neotropical Nymphalidae for example, distances ranged from 3 to 5\% between sister species and from 5 to $8 \%$ between species in the three separate phyletic lineages defined in the genus Anartia (Blum et al. 2003).

Both MP and ML analyses strongly supported clade A, which comprised the two North American species (D. abietivorella and D. ebeli). MtDNA genetic distances between D. abietivorella and D. abietella ranged between 3.3\% and $4.2 \%$ (mean sequence divergence of 0.037 , whatever the fragment length considered, i.e. 1975,451 or $572 b p)$. This result was similar to divergence observed within Tortricidae for the Argyrotaenia franciscana species group (Landry et al. 1999), although these pairwise divergences were higher than these found between most closely related species or within species complexes in Lepidoptera. For example, within the spruce budworm species complex, divergences ranged from $2.7 \%-2.9 \%$ between Choristoneura fumiferana and the other members of the group, divergences between these other members were all <1\% (Sperling and Hickey 1994). Sequence divergence within the Archips argyrospila complex ranged from $1.47 \%$ to $2.53 \%$ between populations of $A$. argyrospila and A. goyerana (Kruse and Sperling 2001). Less than $1 \%$ divergence was observed among three species of ermine moths (Yponomeutidae) (Sperling et al. 1995). In contrast, some swallowtail butterfly species groups showed higher sequence divergences, ranging from 2.6 to $5.4 \%$ in the Papilio machaon group, 1.3 to $3.7 \%$ in the P. glaucus group, and 7.3 to $9.4 \%$ in the P. dardanus group (Caterino and Sperling 1999). 
The high variability of sequence divergence between closely related species of Lepidoptera implies that it is not a good predictor of whether two unknown populations constitute reproductively isolated species (Landry et al. 1999, Sperling 2003, Cognato 2006). Nevertheless, sequence divergence observed within the Dioryctria abietella species group most likely reflects relatively recent separation of the mitochondrial lineages, during the Quaternary ice ages, according to the mtDNA clock of Brower (1994). This pattern has been observed in other sibling species of forest insects (Emelianov et al. 1995, Boato and Battisti 1996, Cognato et al. 1999, Stauffer et al. 1999, Nice and Shapiro 2001). Although D. abietella and D. abietivorella have very close morphological characters and similar degrees of polyphagy and broad geographic ranges, they differ strongly in their distributions, the first one being palearctic and the second one nearctic. According to Hewitt (1996), most species are confined to continents and closely related species often occupy different parts of a continent.

European Dioryctria species of the abietella group fall into two major groups, one comprising species that develop on Mediterranean pine cones (D. mendacella and D. pinae) and the other comprising species that develop on cones of more northern conifers $(D$. abietella and $D$. simplicella). The delimitation between $D$. mendacella and $D$. pineae is not clear. The fact that specimens of $D$. mendacella collected on the same host as $D$. pineae fell into two distinct haplotype lineages could indicate a complex of three cryptic species instead of two, as the two currently recognized species can be found in sympatry on the same hosts (Pinus pinaster, P. halepensis and P. pinea: Roques 1983; Pinus brutia, Karanicola 1998). Nevertheless, further investigation with more extensive sampling of their ecology and genetic variation, especially with nuclear markers, is needed to clarify this result.

The clade represented by $D$. abietella and $D$. simplicella appeared even more problematic. The separation between the two species was not well supported, and three $D$. 
abietella specimens collected on $P$. menziesii and P. smithiana and showing the abt12 haplotype clustered together with specimens of D. simplicella collected on Pinus sylvestris. These three specimens were collected in different localities from $D$. simplicella and, to date, D. simplicella has not been found on Pseudotsuga menziesii or on Picea smithiana. This species is recorded from cones as well as shoots of diverse coniferous species including Pinus sylvestris (Charles and Roques 1977). The morphological characters of adults were clear and no differences in genitalia were noted between these specimens, whereas the genitalia of $D$. simplicella differ greatly from those of D. abietella (Zocchi 1961). Nevertheless, it seems plausible that abt12 specimens were simplicella specimens. Further sampling is clearly needed to clarify the incongruence between morphological and molecular data.

For the North American species, the identity of the two specimens labeled as Dioryctria ebeli is open to question, since the D. ebeli mtDNA haplotype showed only 0.1 to 0.6\% divergence from D. abietivorella haplotypes. Other Dioryctria species also display low sequence divergence (less than $1.8 \%$ separate $D$. zimmermani, $D$. tumicolella and $D$. taedivorella), but morphological characters were not effective in confirming the distinctness of these lineages (Du et al. 2005). As for the European species of the abietella group, additional sampling is clearly needed in order to resolve the specific status of D. ebeli.

Our study confirmed that nucleotide diversity within and between taxa was quite variable across both COI and COII genes. As divergences are low between sister species of Dioryctria, it is crucial to target regions with maximum divergence to ensure the greatest probability of consistently delimiting species boundaries by sequencing regions with the most informative nucleotide variation (Roe and Sperling 2007a). Mitochondrial DNA data may 
compensate for insufficient information from morphological characters, especially at the species and species group levels, but it also shows that currently recognized taxonomic relationships based on morphological similarities and host plant origin need to be reevaluated in the European D. abietella species complex. As an integrative approach is essential to testing species delimitations (Roe et al. 2007b), multiple independent markers such as independent molecular loci (nuclear markers), morphology, larval host plant and geographic range should be also considered to be confident of species delineations. 


\section{Acknowledgements}

We thank G. Grant, G. DeBarr, J. Powell, P. Karamicola and H. Jactel for specimen sampling. We are also grateful to A. Cognato, D. Kain, B. Landry and Anna Engberg for their advice and helpful assistance in molecular work. We also thank C. Kerdelhué and A. Roe for their insighful comments on drafts of the manuscript and an anonymous reviewer for review of the submitted manuscript. This work was supported by California Hatch funds and an NSERC grant to FAHS. 


\section{References}

Avise, J. C. 1991. Ten unorthodox perspectives on evolution prompted by comparative populations genetic findings on mitochondrial DNA. Annu. Rev. Gen. 25: 45-69.

Avise, J. C. 2000. Phylogeography: The History and Formation of Species. Harvard University Press, Cambridge, MA.

Ballard, J. W. O., and M. C. Whitlock. 2004. The incomplete natural history of mitochondria. Mol. Ecol. 13(4): 729-744.

Bensasson, D., D. X. Zhang, D. L. Hartl, G. M. Hewitt. 2001. Mitochondrial pseudogenes: evolution’s misplaced witnesses. Trends Ecol. Evol. 16: 314-321.

Berlocher, S. H., and J. L. Feder. 2002. Sympatric speciation in phytophagous insects: moving beyond controversy? Annu. Rev. Entomol. 47: 773-815.

Bhandari, R. S., J. M. S. Rawat, S. M. H. Kumar, Vinod and Zaidi. 2003. Chemical control of cone worm, Dioryctria abietella, infesting cones of silver fir (Abies pindrow) by systemic insecticides. Indian for. 129(9): 1141-1146.

Blum, J. M., E. Bermingham, and K. Dasmahapatra. 2003. A molecular phylogeny of the neotropical butterfly genus Anartia (Lepidoptera: Nymphalidae). Mol. Phylogen. Evol. 26: 46-55.

Boato, A. and A. Battisti. 1996. High genetic variability despite haplodiploidy in primitive sawflies of the genus Cephalcia (Hymenoptera, Pamphiliidae). Experientia. 52 : 516-521.

Bogdanowicz, S. M., W. E. Wallner, T. M. Bell, and R. G. Harrison. 1993. Asian gypsy moths (Lepidoptera: Lymantriidae) in North America: evidence from molecular data. Ann. Entomol. Soc. Am. 86: 710-715.

Broughton, R. E., and P. C. Reneau. 2006. Spatial covariation of mutation and nonsynonymous substitution rates in vertebrate mitochondrial genomes. Mol. Biol. Evol. 23: $1516-1524$. 
Brower, A. V. Z. and R. DeSalle. 1994. Practical and theoretical considerations for choice of a DNA sequence region in insect molecular systematics, with a short review of published studies using nuclear gene regions. Ann. Entomol. Soc. Am. 87(6): 702-716.

Brower, A. V. Z. 1999. Delimitation of phylogenetic species with DNA sequences: a critique of Davis and Nixon’s population aggregation analysis. Syst. biol. 48: 199-213.

Brown, J. M., O. Pellmyr, J.N. Thompson, and R.G. Harrison. 1994. Phylogeny of Greya (Lepidoptera: Prodoxidae) based on nucleotide sequence variation in mitochondrial cytochrome oxidase I and II: congruence with morphological data. Mol. Biol. Evol.11: 128-141.

Bush, G. L. 1975. Modes of animal speciation. Annu. Rev. Ecol. Syst. 6: 339-364.

Byun, B.K., C.S. Kim, and J.K. Kim. 1998. Taxonomic Notes of Dioryctria abietella and D. sylvetrella (Lepidoptera: Pyralidae) in Korea, KFRI. J. 59: 59-82.

Caterino, M. S. and F. A. H. Sperling. 1999. Papilio phylogeny based on mitochondrial cytochrome oxidase I and II genes. Mol. Phylogen. Evol. 8: 1-16.

Caterino, M. S., S. Cho, and F. A. H. Sperling. 2000. The current state of insect molecular systematics: A thriving tower of Babel. Annu. Rev. Entomol. 45: 1-54.

Charles, P. J., and A. Roques. 1977. Observations sur la biologie et l'écologie de Dioryctria mutatella Fuchs (Lepidoptera Phycitidae), ravageur des pousses et des cônes de Pin sylvestre en forêt de Fontainebleau. Ann. Zool., Ecol. An. 9(1): 117-131.

Chatelain, M. P., and R. A. Goyer. 1980. Seasonal attack periods of cone-feeding insects of loblolly pine cones. Ann. Entomol. Soc. Am. 73:49-53.

Cibrián-Tovar, D., B. H. Ebel, H. O. Yates, and J. T. Méndez-Montiel. 1986. Insectos de conos y semillas de las coníferas de México/Cone and seed insects of the Mexican conifers. U.S. Dept. Agr. Gen. Tech. Rep. SE-40. 110 pp. 
Clary, D. O., and D. R. Wolstenholme. 1985. The mitochondrial DNA molecule of Drosophila yakuba: nucleotide sequence, gene organization, and genetic code. J. Mol. Evol. 22: 252-271.

Clement, M., D. Posada, and K. A. Crandall. 2000. TCS: a computer program to estimate gene genealogies. Mol. Ecol. 9: 1657-1659.

Cognato, A. I, S. J. Seybold, and F. A. H. Sperling. 1999. Incomplete barriers to mitochondrial gene flow between pheromone races of the North American pine engraver, Ips pini (Say) (Coleoptera: Scolytidae). Proc. R. Soc. Lond. B. 266: 1843-1850.

Cognato, A. I. 2006. Standard percent DNA sequence difference for insects does not predict species boundaries. J. Econ. Entomol. 99(4): 1037-1045.

Damgaard, J., and A. I. Cognato. 2006. Phylogeny and reclassification of species groups in Aquarius Schellenberg, Limnoporus Stal and Gerris Fabricius (Insecta: HemipteraHeteroptera, Gerridae). Syst. Entomol. 31(1): 93-112.

Debarr, G. L., J. L. Hanula, C. G. Niwa, and J. C. Nord. 2000. Synthetic pheromones disrupt male Dioryctria spp. moths in a loblolly pine seed orchard. Can. Entomol. 132(3): 345-351.

Denis, M., and J. Schiffermüller. 1776. Systematische Werzeichniss der Schmetterlinge der Wienergegend. Vienna. 322pp., 2pl.

Diehl, S. R., and G. L. Bush. 1984. An evolutionary and applied perspective of insect biotypes. Annu. Rev. Entomol. 29: 471-504.

Dres, M. and J. Mallet. 2002. Host races in plant-feeding insects and their importance in sympatric speciation. Philos. T. Roy. Soc. B. 357(1420): 471-492.

Du, Y., A. D. Roe, and F. A. H. Sperling. 2005. Phylogenetic framework for Dioryctria (Lepidoptera: Pyralidae) based on combined analysis of mitochondrial DNA and morphology. Can. Entomol. 137: 685-711. 
Emelianov, I., J. Mallet, and W. Baltensweiler. 1995. Genetic differentiation in Zeiraphera diniana (Lepidoptera: Tortricidae, the larch budmoth): polymorphism, host races or sibling species? Heredity. 75: 416-424.

Emelianov, I., M. Drès, W. Baltensweiler, and J. Mallet. 2001. Host-induced assortative mating in host races of the larch budmoth. Evolution. 55(10): 2002-2010.

Excoffier, L., P. E. Smouse, and J. M. Quattro. 1992. Analysis of molecular variance inferred from metric distances among DNA haplotypes: Application to human mitochondrial DNA restriction data. Genetics. 131(2): 479-491.

Farris, J. S., M. Källersjo, A. G. Kluge, and C. Bult . 1994. Testing significance of incongruence. Cladistic. 10:315-319.

Fazekas, I., 2002. Systematisches und synonymisches Verzeichnis der Microlepidopteren Ungarns (Lepidoptera: Microlepidoptera). Folia Hist.-nat. Mus. Matr. 26: 289-327

Felsenstein, J. 1985. Confidence limits on phylogenies: an approach using the bootstrap. Evolution. 39(4): 783-791.

Funk, D. J., and K. E. Omland. 2003. Species-level paraphyly and polyphyly: frequency, causes and consequences, with insights from animal mitochondrial DNA. Annu. Rev. Ecol. Evol. S. 34: 397-423.

Galtier, N., D. Enard, Y. Ranondy, E. Bazin, and K. Belkhir. 2006. Mutation hot spots in mammalian mitochondrial DNA. Genome Research. 16, 215-222.

Glynn, C., and J. Weslien. 2004. Bacillus thuringiensis variety kurstaki x aizawai applied to spruce flowers reduced Dioryctria abietella (Lepidoptera: Pyralidae) infestation without affecting seed quality. J. Econ. Entomol. 97(6): 1836-1841.

Grant, G. G., S. A. Katovich, D. J. Hall, D. A. Lombardo, and K. N. Slessor. 1993. Sexpheromone identification and trapping of Dioryctria resinosella (Lepidoptera, Pyralidae). Environ. Entomol. 22: 154-161. 
Grossman, D. M., W. W. Upton, F. A. McCook, and R. F. Billings. 2002. Systemic insecticide injections for control of cone and seed insects in Loblolly Pine seed orchards2 year results. South. J. Appl. For. 26(3): 146-152.

Hajibabaei, M., D. H. Janzen, J. M. Burns, W. Hallwachs, and D. N. Hebert. 2006. DNA barcodes distinguish species of tropical Lepidoptera. PNAS. 103(4): 968-971.

Hebert, P. D. N., A. Cywinska, S. L. Ball, and J. R. deWaard. 2003a. Biological identifications through DNA barcodes. Proc. R. Soc. Lond. B. 270: 313-322.

Hebert, P.D.N., S. Ratnasingham, and J.R. deWaard. 2003b. Barcoding animal life: cytochrome c oxidase subunit 1 divergences among closely related species. Proc. R. Soc. Lond. B. Biol. (Suppl. 27), S96-S99.

Hedlin, A.F., H.O. Yates III, D. Cibrian-Tovar, B.H. Ebel, T.W. Koerber, and E.P.

Merkel. 1980. Cone and Seed insects of North America Conifers. Joint publication:

Canadian Forestry Service, USDA Forest Service, and Secretaría de Agricultura y Recursos Hidráulicos, Mexico. 122 pp.

Hewitt , G. M. 1996. Some genetic consequences of ice ages, and their role in divergence and speciation. Biol. J. Linn. Soc. 58: 247-276.

Innan, H., and M. Nordborg. 2002. Recombination or mutational hot spots in human mtDNA? Mol. Biol. Evol. 19, 1122-1127.

Jactel, H., P. G. Menassieu, G. Raise. 1994. Infestation dynamics of Dioryctria sylvestrella (Ratz.) (Lepidoptera: Pyralidae) in pruned maritime pine (Pinus pinaster Ait.). Forest Ecol. Manag. 67: 11-22.

Johnson, P. A., F. C. Hoppensteadt, J. J. Smith, and G. L. Bush. 1996. Conditions for sympatric speciation: a diploid model incorporating habitat fidelity and nan-habitat assortative mating. Evol. Ecol. 10:187-205. 
Karanicola, P. 1998. Biology, ecology and damage of cone and seed insects on Pinus brutia (in Greek). Unpublished PhD thesis, Univ. Thessaloniki, 198 pp.

Keller, I., D. Bensasson, and R. A. Nichols. 2007. Transition-transversion bias is not universal: a counter example from grasshopper pseudogenes. Genetics 3: 185-191.

Kelley, S. T., J. B. Mitton, T. D. Paine. 1999. Strong differentiation in mitochondrial DNA of Dendroctonus brevicomis (Coleoptera: Scolytidae) on different subspecies of Ponderosa pine. Ann. Entomol. Soc. Am. 92(2): 194-197.

Kerdelhué, C., and J. Y. Rasplus. 2002. Le séquençage des acides nucléiques et les méthodes d'analyse des données moléculaires en phylogénie. Ann. Soc. Entomol. Fr. 6: 97-122.

Kerdelhué, C., G. Roux-Morabito, J. Forichon, J. M. Chambon, A. Robert, and F. Lieutier. 2002. Population genetic structure of Tomicus piniperda L. (Curculionidae: Scolytinae) on different pine species and validation of T. destruens (Woll.). Mol. Ecol. 11: 483-494.

Knölke, S., S. Erlacher, A. Hausmann, M. A. Miller, and A. Segerer. 2005. A procedure for combined genitalia dissection and DNA extraction in Lepidoptera. Ins. Syst. Evol. 35: 401-409.

Koutroumpa, F., F. Lieutier, and G. Roux-Morabito. (2008). Incorporation of mitochondrial fragments in the nuclear genome (Numts) of the longhorned beetle Monochamus galloprovincialis (Coleoptera Cerambycidae). J. Zool. Syst. Evol. Res. (in press)

Kruse, J. J., and F. A. H. Sperling. 2001. Molecular phylogeny within and between species of the Archips argyrospila complex (Lepidoptera: Tortricidae). Ann. Entomol. Soc. Am. 94: 166-173. 
Landry, B., J. A. Powell, and F. A. H. Sperling. 1999. Systematics of the Argyotaenia franciscana ( Lepidoptera: Tortricidae) species group: evidence from mitochondrial DNA. Ann. Entomol. Soc. Am. 92: 40-46.

Lyons, L. A., 1957. Insetcs affecting seed production in red pine. II. Dioryctria disclusa Heinrich, D. abietella (D. \& S.), and D. cambiicola (Dyar.) (Lepidoptera: Phycitidae). Can. Entomol. 89: 70-79.

Lunt, D. H., D.-X. Zhang, J. M. Szymura, and G. M. Hewitt. 1996. The insect cytochrome oxidase I gene: evolutionary patterns and conserved primers for phylogenetic studies. Ins. Mol. Biol. 5, 153-165.

Menken, S. B. J. 1996. Pattern and process in the evolution of insect-plant associations: Yponomeuta as an example. Entomol. Exp. Appl. 80 : 297-305.

Merkel, E. P., 1984. The Baldcypress coneworm Dioryctria pygmaeella Ragonot (Lepidoptera: Pyralidae). In: Proceedings of the Cone and Seed Insects working party conference, I.U.F.R.O. July 31-August 6, 1983, Athens (H.O. Yates III, ed.), Southearsten Forest Experiment Station, Asheville, North Carolina USA, 194-201.

\section{Millar, J. G., G. G. Grant, J. Steven McElfresh, W. Strong, C. Rudolf, J. D. Stein, and J.} A. Moreira. 2005. (3Z, 6Z, 9Z, 12Z, 15Z)-pentacosapentaene, a key pheromone component of the fir coneworm moth Dioryctria abietivorella. J. Chem. Ecol. 31: 12291234.

Mitter, C., and D. J. Futuyma. 1979. Population genetic consequences of feeding habits in some forest Lepidoptera. Genetics. 92(3): 1005-1021.

Moore, W. S. 1995. Inferring phylogenies from mtDNA variation : mitochondrial-gene trees versus nuclear-gene trees. Evolution. 49(4) :718-726.

Mopper, S., and S. Y. Strauss. 1998. Genetic structure and local adaptation in natural insect populations. Effects of ecology, life history and behavior. Chapman et Hall, New York. 
Munroe, E. 1959. Canadian species of Dioryctria Zeller (Lepidoptera: Pyralidae). Can. Entomol. 91: 65-72.

Mutuura, A. and E. Munroe. 1972. American species of Dioryctria (Lepidoptera: Pyralidae) III. Grouping of species: species of the auranticella group, including the Asian species, with the description of a new species. Can. Entomol. 104 (5): 609-625.

Mutuura, A. and E. Munroe. 1973. American species of Dioryctria (Lepidoptera: Pyralidae). IV. The schuetzeella group and the taxonomic status of the spruce cone moth. Can. Entomol. 105: 653-668.

Neunzig, H. H., E. D. Cashatt, and G. A. Matuza. 1964. Observations on the biology of four species of Dioryctria in North Carolina (Lepidoptera: Phycitidae). Ann. Entomol. Soc. Am. 57: 317-321.

Neunzig, H. H. 1990. A new species of Dioryctria (Pyralidae: Phycitinae) from Mexico. Proc. Entomol. Soc. Wash. 92: 493-496.

Neunzig, H. H. 2003. Pyraloidea, Pyralidae (part), Phycitinae (part): R. B. Dominick, et al. The Moths of America North of Mexico, fasc. 15.5. The Wedge Entomological Research Foundation, National Museum of Natural History, Washington, DC.

Nice, C. C., and A. M. Shapiro. 2001. Population genetic evidence of restricted gene flow between host races in the butterfly genus Mitoura (Lepidoptera: Lycaenidae). Ann. Entomol. Soc. Am. 94: 257-267.

Perez, M., F. Palacios, I. C. Diaz, M. O. Lopez, M. L. Martinez, and L. G. Perez. 1999. Pr 1-3, a new entomopathogenic isolate of Beauveria bassiana (Bals.) Vuill. in Cuba. Revista-de-Proteccion-Vegetal. 14(1): 63-64.

Posada, D., and K. A. Crandall. 1998. MODELTEST: testing the model of DNA substitution. Bioinformatics. 14(9): 817-818. 
Richmond, J. A., and M. Page. 1995. Genetic and biochemical similarities among four species of pine coneworms (Lepidoptera: Pyralidae). Ann. Entomol. Soc. Am. 88: 271280.

Roe, A. D., J. D. Stein, N. E. Gillette, and F. A. H. Sperling. 2006. Identification of Dioryctria (Lepidoptera: Pyralidae) in a seed orchard at Chico, California. Ann. Entomol. Soc. Am. 99: 433-448.

Roe, A.D., and F.A.H. Sperling. 2007a. Patterns of evolution of mitochondrial cytochrome c oxidase I and II DNA and implications for DNA barcoding. Mol. Phylogen. Evol. doi:10.1016/j.ympev.2006.12.005

Roe, A.D., and F.A.H. Sperling. 2007b. Population structure and species boundary delimitation of cryptic Dioryctria moths : an integrative approah. Mol. Ecol. Doi : 10.1111/j.1365-294X.2007.03412

Roques, A. 1983. Les insectes ravageurs des cônes et graines de conifères en France. INRA, Versailles, 135 p.

Rundle, H. D., and P. Nosil. 2005. Ecological speciation. Ecology Letters. 8 : 336-352.

Schwenke, W. 1982. Die Forstschiidlinge Europas. Bd. 4. Hautflugler und Zweifliigler. Paul Parey, Hamburg-Berlin.

Segerer, A.H. and H. Pröse. 1997. Dioryctria resiniphila sp. nov., eine neue Pyralide auf Abies cephalonica Loud. in Griechenland (Lepidoptera: Pyralidae: Phycitinae). NachrBl. bayer. Ent. 46: 57-67.

Simon, C., F. Frati, A. Beckenbach, B. Crespi, H. Liu, and P. Flook. 1994. Evolution, weighting, and phylogenetic A.utility of mitochondrial gene sequences and a compilation of conserved polymerase chain reaction primers. Ann. Entomol. Soc. Am. 87: 651-701. 
Sopow, S. L., R. G. Bennet, J.-F. Landry, and B. Landry. 1996. Identification of the "grey' Dioryctria species of British Columbia (Lepidoptera: Pyralidae). J. Entomol. Soc. B. Col. 93: 75-91.

Sperling, F. A. H. 2003. Butterfly molecular systematics: from species definitions to higher level phylogenies. Pp. 431-458. IN Boggs, C., P. Ehrlich, and W. Watt. (Eds). Ecology and Evolution Taking Flight: Butterflies as Model Study Systems. University of Chicago Press, Chicago.

Sperling, F. A. H. , G. S. Anderson, and D. A. Hickey. 1994. A DNA-based approach to identification of insect species used for postmortem interval estimation. J. Forensic Sci. 39: 418-427.

Sperling, F. A. H. and D. A. Hickey. 1994. Mitochondrial DNA sequence variation in the spruce budworm species complex (Choristoneura: Lepidoptera). Mol. Biol. Evol. 11: 656-665.

Sperling, F. A. H., J.- F.Landry, and D. A. Hickey. 1995. DNA-based identification of introduced ermine moth species in North America (Lepidoptera: Yponomeutidae). Ann. Entomol. Soc. Am. 88: 155-162.

Stauffer, C., F. Lakatos, and G. M. Hewitt. 1999. Phylogeography and postglacial colonization routes of Ips typographus L. (Coleoptera, Scolytidae). Mol. Ecol. 8: 763774.

Stoneking, M. 2000. Hypervariable sites in the mtDNA control region are mutational hotspots. Am. J. Hum. Gen. 67: 1029-1032.

Stump, A. D., F. A. H. Sperling, A. Crim, and J. M. Scriber. 2003. Gene flow between Great Lakes region populations of the tiger swallowtail butterfly, Papilio canadensis, near the hybrid zone with P. glaucus (Lepidoptera: Papilionidae). Great Lakes Entomologist. 36: 41-53. 
Swofford, D. L. 2002. PAUP*. Phylogenetic analysis using parsimony. Version 4 beta 10. Sinauer Associates, Sunderland, MA.

Tauber, C. A., and M. J. Tauber. 1989. Sympatric speciation in insects: perception and perspective. In speciation and its consequences. Eds D. Otte and J. A. Endler. pp. 307344. Sunderland, MA Sinauer Associates.

Tavaré, S. 1986. Some probabilistic and statistical problems in the analysis of DNA sequences. In: Some mathematical questions in biology - DNA sequence analysis (ed. Miura RM), pp. 57-86. Amer. Math. Soc., Providence, RI.

Templeton, A. R. 2001. Using phylogeographic analyses of gene trees to test species status and processes. Mol. Ecol. 10(3): 779-791.

Turgeon, J. J., A. Roques, and P. DeGroot. 1994. Insect fauna of coniferous seed cones Diversity, host-plant interactions and management. Annu. Rev. Entomol. 39: 179-212.

Turgeon, J.J., and P. DeGroot. 1992. Management of Insect Pests of Cones in Seed

Orchards in Eastern Canada. Forestry Canada, Toronto (CA).

Verma, T. D., Ram-Karann, and K. S. Verma. 1996. Natural enemies of Dioryctria abietella Denis \& Schiff., a pest of conifers in the north-west Himalaya. Pest Management and Economic Zoology. 4(1/2): 115-117.

Wahlberg, N., R. Oliveira, and J. A. Scott. 2003. Phylogenetic relationships of Phyciodes butterfly species (Lepidoptera: Nymphalidae): complex mtDNA variation and species delimitations. Syst. Entomol. 28: 257-273.

Wells, J. D. and F. A. H. Sperling. 1999. Molecular phylogeny of Chrysomya albiceps and C. ruffifacies (Diptera: Calliphoridae). J. Med. Entomol. 36: 222-226.

Zocchi, R. 1961. Contributi alla conoscenza degli insetti delle piante forestali. V. Il gen. Dioryctria Zell. (Lepidoptera, Pyralidae) in Italia. Redia. 46: 9-143. 
Table 1. Collection and sequence data for specimens used in this study.

\begin{tabular}{|c|c|c|c|c|c|c|}
\hline \multirow[t]{2}{*}{ Identification $^{\mathrm{a}}$} & \multirow[t]{2}{*}{ Abbreviation } & \multirow{2}{*}{$\begin{array}{l}\text { Haplotype } \\
\text { (number of } \\
\text { specimens) }\end{array}$} & \multirow{2}{*}{$\begin{array}{l}\text { Host tree } \\
\text { species }\end{array}$} & \multirow[t]{2}{*}{ Locality ${ }^{\mathrm{e}}$} & \multicolumn{2}{|c|}{ GenBank accession no. } \\
\hline & & & & & 451bp COI & 572bp COII \\
\hline D. abietella & abieTUE & $\operatorname{abt1}(3)^{c}$ & Picea abies & $\begin{array}{l}\text { France, Alps, Tueda, } \\
\text { Meribel, 1750m } \\
\text { (mixed forest of Swiss } \\
\text { stone pine and spruce) } \\
\text { (nat) }\end{array}$ & EU407723 & EU407749 \\
\hline D. abietella & cembTUE & $\begin{array}{l}\text { abt1 }(3)^{\mathrm{c}} \\
\text { abt2 (1) }\end{array}$ & $\begin{array}{l}\text { Pinus } \\
\text { cembra }\end{array}$ & $\begin{array}{l}\text { France, Alps, Tueda, } \\
\text { Meribel, 1750m } \\
\text { (mixed forest of Swiss } \\
\text { stone pine and spruce) } \\
\text { (nat) }\end{array}$ & $\begin{array}{l}\text { EU407723 } \\
\text { EU407724 }\end{array}$ & $\begin{array}{l}\text { EU407749 } \\
\text { EU407750 }\end{array}$ \\
\hline D. abietella & cembBOS & abt1 (4) & $\begin{array}{l}\text { Pinus } \\
\text { cembra }\end{array}$ & $\begin{array}{l}\text { Italy, Alps, Bosco } \\
\text { Aleve, Casteldelfino, } \\
\text { 1600-1800m (large } \\
\text { forest of Swiss stone } \\
\text { pine) (nat) }\end{array}$ & EU407723 & EU407749 \\
\hline D. abietella & abieLAT & $\begin{array}{l}\text { abt1 }(1), \\
\text { abt5 (1), } \\
\text { abt6 (1), } \\
\text { abt9 (1), }\end{array}$ & Picea abies & $\begin{array}{l}\text { France, Latronquière } \\
\text { seed orchard, Lot (art) }\end{array}$ & $\begin{array}{l}\text { EU407723 } \\
\text { EU407727 } \\
\text { EU407728 } \\
\text { EU407731 }\end{array}$ & $\begin{array}{l}\text { EU407749 } \\
\text { EU407753 } \\
\text { EU407754 } \\
\text { EU407757 }\end{array}$ \\
\hline D. abietella & menzLAT & $\begin{array}{l}\text { abt1 }(1), \\
\text { abt3 }(1), \\
\text { abt8 }(1), \\
\text { abt12 (1) }\end{array}$ & $\begin{array}{l}\text { Pseudotsuga } \\
\text { menziesii }\end{array}$ & $\begin{array}{l}\text { France, Latronquière } \\
\text { seed orchard, Lot (art) }\end{array}$ & $\begin{array}{l}\text { EU407723 } \\
\text { EU407725 } \\
\text { EU407730 } \\
\text { EU407734 }\end{array}$ & $\begin{array}{l}\text { EU407749 } \\
\text { EU407751 } \\
\text { EU407756 } \\
\text { EU407760 }\end{array}$ \\
\hline D. abietella & deciLAT & $\begin{array}{l}\text { abt1 (1), } \\
\text { abt7 (1) }\end{array}$ & $\begin{array}{l}\text { Larix } \\
\text { decidua }\end{array}$ & $\begin{array}{l}\text { France, Latronquière } \\
\text { seed orchard, Lot (art) }\end{array}$ & $\begin{array}{l}\text { EU407723 } \\
\text { EU407729 }\end{array}$ & $\begin{array}{l}\text { EU407749 } \\
\text { EU407755 }\end{array}$ \\
\hline D. abietella & smitBAR & $\begin{array}{l}\text { abt4 (1), } \\
\text { abt10 (2), } \\
\text { abt12 (2) }\end{array}$ & $\begin{array}{c}\text { Picea } \\
\text { smithiana }\end{array}$ & $\begin{array}{l}\text { France, Les Barres } \\
\text { Arboretum, Loiret } \\
\text { (art) }\end{array}$ & $\begin{array}{l}\text { EU407726 } \\
\text { EU407732 } \\
\text { EU407734 }\end{array}$ & $\begin{array}{l}\text { EU407752 } \\
\text { EU407758 } \\
\text { EU407760 }\end{array}$ \\
\hline D. abietella & koraBAR & $\begin{array}{l}\text { abt10 (1) } \\
\text { abt11 (1) }\end{array}$ & $\begin{array}{l}\text { Pinus } \\
\text { koraiensis }\end{array}$ & $\begin{array}{l}\text { France, Les Barres } \\
\text { Arboretum, Loiret } \\
\text { (art) }\end{array}$ & $\begin{array}{l}\text { EU407732 } \\
\text { EU407733 }\end{array}$ & $\begin{array}{l}\text { EU407758 } \\
\text { EU407759 }\end{array}$ \\
\hline $\begin{array}{l}\text { D. abietella-ref.: } \\
\text { Du et al. (2005) }\end{array}$ & Du64Ch & abt13 (1) & unknown & $\begin{array}{l}\text { China, Henan } \\
\text { Province, Mt. Baiyun }\end{array}$ & DQ247739 & DQ247739 \\
\hline D. simplicella & SylvFON & $\operatorname{sim} 1(2)$ & $\begin{array}{l}\text { Pinus } \\
\text { sylvestris }\end{array}$ & $\begin{array}{l}\text { France, Fontainebleau, } \\
\text { Yvelines }\end{array}$ & EU407741 & EU407767 \\
\hline D. simplicella & SylvJPOL & $\operatorname{sim} 2(2)$ & $\begin{array}{l}\text { Pinus } \\
\text { sylvestris }\end{array}$ & Poland Jedinia 300m & EU407742 & EU407768 \\
\hline D. simplicella & SylvZPOL & $\operatorname{sim} 2(4)$ & $\begin{array}{c}\text { Pinus } \\
\text { sylvestris }\end{array}$ & Poland Zawady 220m & EU407742 & EU407768 \\
\hline
\end{tabular}




\begin{tabular}{|c|c|c|c|c|c|c|}
\hline Identification $^{\mathrm{a}}$ & Abbreviation & $\begin{array}{l}\text { Haplotype } \\
\text { (number of } \\
\text { specimens) }\end{array}$ & $\begin{array}{l}\text { Host tree } \\
\text { species }\end{array}$ & Locality ${ }^{\mathrm{e}}$ & \multicolumn{2}{|c|}{ GenBank accession no. } \\
\hline D. mendacella & HalTUN & $\begin{array}{l}\text { mend1 (1), } \\
\text { mend2 (1), } \\
\text { mend3 (1), } \\
\text { mend4 (1), } \\
\text { mend5 (1) }\end{array}$ & $\begin{array}{l}\text { Pinus } \\
\text { halepensis }\end{array}$ & $\begin{array}{l}\text { Tunisia, Jebel Bel } \\
\text { Oulid }\end{array}$ & $\begin{array}{l}\text { EU407735 } \\
\text { EU407736 } \\
\text { EU407737 } \\
\text { EU407738 } \\
\text { EU407739 }\end{array}$ & $\begin{array}{l}\text { EU407761 } \\
\text { EU407762 } \\
\text { EU407763 } \\
\text { EU407764 } \\
\text { EU407765 }\end{array}$ \\
\hline D. mendacella & HalTUN2 & mend5 (1) & $\begin{array}{l}\text { Pinus } \\
\text { halepensis }\end{array}$ & $\begin{array}{l}\text { Tunisia, Kasserine Ft. } \\
\text { Oum Jeddour }\end{array}$ & EU407739 & EU407765 \\
\hline D. mendacella & HalFR & $\begin{array}{l}\text { mend5 } \\
(2)\end{array}$ & $\begin{array}{l}\text { Pinus } \\
\text { halepensis }\end{array}$ & France, Venelles, 13 & EU407739 & EU407765 \\
\hline D. mendacella & PinTUN & $\begin{array}{l}\text { mend5 } \\
\text { (1) }\end{array}$ & $\begin{array}{l}\text { Pinus pinae } \\
\text { (Linnaeus) }\end{array}$ & $\begin{array}{l}\text { Tunisia (Sejnane Ft. } \\
\text { M’Hibeus) }\end{array}$ & EU407739 & EU407765 \\
\hline D. pineae & HalGR & $\operatorname{pin} 1(2)$ & $\begin{array}{c}\text { Pinus } \\
\text { halepensis }\end{array}$ & Greece, Thessaloniki & EU407740 & EU407766 \\
\hline D. abietivorella & LambLG & $\operatorname{abv1}(3)^{d}$ & $\begin{array}{c}\text { Pinus } \\
\text { lambertiana } \\
\text { (Douglas) }\end{array}$ & $\begin{array}{l}\text { USA, Oregon, La } \\
\text { Grande }\end{array}$ & EU407720 & EU407746 \\
\hline D. abietivorella & MenzCHI & abv1 (2) & $\begin{array}{l}\text { Pseudotsuga } \\
\text { menziesii }\end{array}$ & $\begin{array}{l}\text { USA, California, Butte } \\
\text { Co., Chico }\end{array}$ & EU407720 & EU407746 \\
\hline D. abietivorella & StrobSM & $\begin{array}{l}\text { abv2 (1) } \\
\text { abv3 (1) }\end{array}$ & $\begin{array}{c}\text { Pinus } \\
\text { strobus } \\
\text { (Linnaeus) }\end{array}$ & $\begin{array}{l}\text { Canada, Ontario, Sault } \\
\text { Ste Marie }\end{array}$ & $\begin{array}{l}\text { EU407721 } \\
\text { EU407722 }\end{array}$ & $\begin{array}{l}\text { EU407747 } \\
\text { EU407748 }\end{array}$ \\
\hline D. abietivorella & LambGP & abv1 (2) & $\begin{array}{c}\text { Pinus } \\
\text { lambertiana }\end{array}$ & $\begin{array}{l}\text { USA, Oregon, Grants } \\
\text { Pass }\end{array}$ & EU407720 & EU407746 \\
\hline $\begin{array}{l}\text { D. abietivorella - } \\
\text { ref.: Roe et al. } \\
(2006)\end{array}$ & Du04CHI & abv4 (1) & unknown & $\begin{array}{l}\text { USA, California, Butte } \\
\text { Co., Chico }\end{array}$ & DQ247740 & DQ247740 \\
\hline $\begin{array}{l}\text { D. abietivorella - } \\
\text { ref.: Roe et al. } \\
(2006)\end{array}$ & Du05CHI & abv5 (1) & unknown & $\begin{array}{l}\text { USA, California , } \\
\text { Butte Co., Chico }\end{array}$ & DQ247741 & DQ247741 \\
\hline D. ebeli & TaedaWSO & ebe1 (2) & $\begin{array}{c}\text { Pinus taeda } \\
\text { (Linnaeus) }\end{array}$ & $\begin{array}{l}\text { USA, North Carolina, } \\
\text { Weyerhaeser seed } \\
\text { orchard }\end{array}$ & EU400415 & EU400416 \\
\hline D. sylvestrella & PstLAN & sylv1 (2) & $\begin{array}{l}\text { Pinus } \\
\text { pinaster } \\
\text { (Aiton) }\end{array}$ & France (Landes) & EU407743 & EU407769 \\
\hline D. amatella & TaedaWSO & ama1 (2) & Pinus taeda & $\begin{array}{l}\text { USA, North Carolina, } \\
\text { Weyerhaeser seed } \\
\text { orchard }\end{array}$ & EU407745 & EU407771 \\
\hline D. pseudotsugella & pseudotsug & $\operatorname{psg} 1(1)^{d}$ & Pinus sp. & $\begin{array}{l}\text { USA, Nevada, Clark } \\
\text { Co, McWilliams } \\
\text { Campgr. (8500’ Mt } \\
\text { Charleston) }\end{array}$ & EU407744 & EU407770 \\
\hline D. reniculelloides & renicul & $\begin{array}{l}\text { ren1 (1) } \\
\text { FS.b-371 }\end{array}$ & $\begin{array}{l}\text { Picea glauca } \\
\text { (Moench) }\end{array}$ & $\begin{array}{l}\text { Canada, Alberta, } \\
\text { Manning, Hawk Hills }\end{array}$ & & \\
\hline
\end{tabular}




\begin{tabular}{|c|c|c|c|c|c|}
\hline Identification ${ }^{\mathrm{a}}$ & Abbreviation & $\begin{array}{l}\text { Haplotype } \\
\text { (number of } \\
\text { specimens) }\end{array}$ & $\begin{array}{l}\text { Host tree } \\
\text { species }\end{array}$ & Locality ${ }^{\mathrm{e}}$ & GenBank accession no. \\
\hline $\begin{array}{l}\text { Oncocera faecella- } \\
\text { ref.: Du et al. } \\
\text { (2005) }\end{array}$ & Du29 & $\begin{array}{l}\text { oncocera } \\
\text { (1) }\end{array}$ & & $\begin{array}{l}\text { China, Inner } \\
\text { Mongolia, Mt Manhan }\end{array}$ & DQ247727 \\
\hline $\begin{array}{l}\text { Ceroprepes } \\
\text { ophthalmicella- } \\
\text { ref.: Du et al. } \\
\text { (2005) }\end{array}$ & Du79 & $\begin{array}{l}\text { ceroprep } \\
\text { es(1) }\end{array}$ & & $\begin{array}{l}\text { China, Henan } \\
\text { Province, Mt Baiyun }\end{array}$ & DQ247728 \\
\hline $\begin{array}{l}\text { Note : All specim } \\
\text { of COII (primers } \\
\text { a }{ }^{\mathrm{a}} \text { based on morph } \\
{ }^{\mathrm{b}} \text { haplotypes as in } \\
{ }^{\mathrm{c}} \text { one specimen se } \\
{ }^{\mathrm{d}} \text { one specimen se } \\
{ }^{\mathrm{e}} \text { Natural forest }\end{array}$ & $\begin{array}{l}\text { hs were sequ } \\
\text { 10-pierre al } \\
\text { ogical chara } \\
\text { ig. } 1,2,3 \text {, } \\
\text { uenced over } \\
\text { uenced over } \\
\text { at) and artif }\end{array}$ & $\begin{array}{l}\text { nced over } 4 \\
\text { d 12-eva), e } \\
\text { ters or larva } \\
975 \text { bp of C } \\
272 \text { bp of C } \\
\text { cial planta }\end{array}$ & $\begin{array}{l}\text { bp of CO } \\
\text { pt where } \\
\text { sst plant. } \\
\text { tRNA les } \\
\text { tRNA let } \\
\text { hs (art) a }\end{array}$ & $\begin{array}{l}\text { (primers } n^{\circ} 4 \text {-jerry an } \\
\text { dicated. } \\
\text { nd COII. } \\
\text { nd COII. } \\
\text { n Table } 4 \text { (AMOVA }\end{array}$ & 7-mila) and 572 bp \\
\hline
\end{tabular}


Table 2. List of primers used for PCR amplification and sequencing.

\begin{tabular}{|c|c|c|c|}
\hline Location* & $\begin{array}{c}\mathrm{N} \\
\mathrm{O}\end{array}$ & Reference & Sequence (5’-3’) \\
\hline TY-J-1460a & 0 & Sperling et al. (1994) & TACAATTTATCGCCTAAACTTCAGCC \\
\hline C1-J-1709 & 1 & Stump et al. (2003) & ATAATTGGAGGATTTGGAAATTG \\
\hline C1-J-1751a & 2 & Bogdanowicz 1993 & GGATCACCTGATATAGCATTCCC \\
\hline C1-N-1945 & 3 & Stump et al. (2003) & ATTGTAGTAATAAAATTAATTGCTCC \\
\hline C1-J-2183a & 4 & Simon et al. (1994) & CAACATTTATTTTGATTTTTTGG \\
\hline C1-N-2191 & 5 & Bogdanowicz 1993 & CCCGGTAAAATTAAAATATAAACTTC \\
\hline C1-J-2441 & 6 & New & ACAGGWATTAAAATTTTTAGTTGATTAGC \\
\hline C1-N-2659d & 7 & New & GTTAGTCCTGTAAATAGAGG \\
\hline C1-J-2792b & 8 & Wells and Sperling (1999) & ATACCTCGGCGATACTCTGA \\
\hline C1-N-2800 & 9 & Sperling et al. (1994) & CATTTCAAGYTGTGTAAGCATC \\
\hline C2-J-3138a & 10 & Sperling et al. (1995) & AGAGCСTCTCСTTTAATAGAACA \\
\hline C2-N-3389b & 11 & Du et al. (2005) & TCATAWCTTCARTATCATTG \\
\hline TK-N-3775 & 12 & Bogdanowicz et al. (1993) & GAGACCATTACTTGCTTTCAGTCATCT \\
\hline
\end{tabular}

* following Simon et al. (1994) 
Table 3. Comparison of uncorrected sequence divergences (mean pairwise divergences) within lineage (within $D$. abietella), between lineages (within $D$. abietella species group) and between species groups for Dioryctria haplotypes defined from 451bp of COI, 572bp of $\mathrm{COII}$ and across both $\mathrm{COI}+\mathrm{COII}$.

Within lineage

Between lineages

Between species groups

\author{
COI \\ $0-0,011(0,002)$ \\ $0,011-0,049(0,027)$ \\ $0,051-0,086(0,068)$
}

COII
$0-0,035(0,018)$
$0,014-0,044(0,029)$
$0,049-0,096(0,074)$

COI+COII
$0-0,023(0,010)$
$0,011-0,045(0,027)$
$0,057-0,086(0,069)$ 
Table 4. Analysis of molecular variance (AMOVA) among European populations of $D$. abietella, with grouping by geographic region, by host species, and by origin of host. ${ }^{*} \mathbf{p}<0,05 ; * * \mathbf{p}<0,01 ;$ NS: Non Significant.

\begin{tabular}{llcc}
\hline & Source of variation & Variance components & Percentage of variation \\
\hline Grouping & Among groups & $3,30165 \mathrm{Va}$ & $51.08 \%^{* *}$ \\
by region & Among populations within groups & $0 \mathrm{Vb}$ & 0 \\
$(1)$ & Within populations & $3,16250 \mathrm{Vc}$ & $48.92 \%^{*}$ \\
Grouping & Among groups & $0,10220 \mathrm{Va}$ & $1.85 \% \mathrm{NS}$ \\
by host (2) & Among populations within groups & $2,20925 \mathrm{Vb}$ & $40.04 \% \mathrm{NS}$ \\
& Within populations & $3,20596 \mathrm{Vc}$ & $58.11 \%^{* *}$ \\
Grouping & Among groups & $4,04406 \mathrm{Va}$ & $55.6 \%^{*}$ \\
by origin & Among populations within groups & $0,06708 \mathrm{Vb}$ & $0.92 \%^{*}$ \\
of host (3) & Within populations & $3,16250 \mathrm{Vc}$ & $43.48 \%^{* *}$ \\
\hline
\end{tabular}

(1) 3 regions $=1$. Alps (French and Italian), 2. central France (Les Barres Arboretum, Fontainebleau), and 3. southwestern France (Latronquière seed orchard)

(2) As in Table 1.

(3) 2 groups $=1$. natural forest, 2 . artificial plantations (see Table 1). 
Fig. 1. Sampling sites and haplotype distributions for $12 \mathrm{mtDNA}$ haplotypes detected in European populations of Dioryctria abietella (abt1 to abt12), plus the French haplotype of D. simplicella (sim1). Each haplotype is defined as in Table 1.

Fig. 2. Phylograms of the consensus tree for parsimony analysis (MP) and maximum likelihood (ML) of haplotypes representing Dioryctria species and 2 outgroup species, for a combined data set COI (451bp) + COII (572bp). Bootstrap support values of $>50 \%$ are shown above branches (500 and 100 replicates for MP and ML analysis respectively).

Fig. 3. Haplotype network for 13 mtDNA haplotypes detected in populations of Dioryctria abietella. Each line between circles represents one mutational change. Small empty circles represent inferred, undetected interior haplotypes. Haplotype frequencies are approximated by the area of the circle. Each haplotype is defined as in Table 1, with different pattern codes for host tree species. 


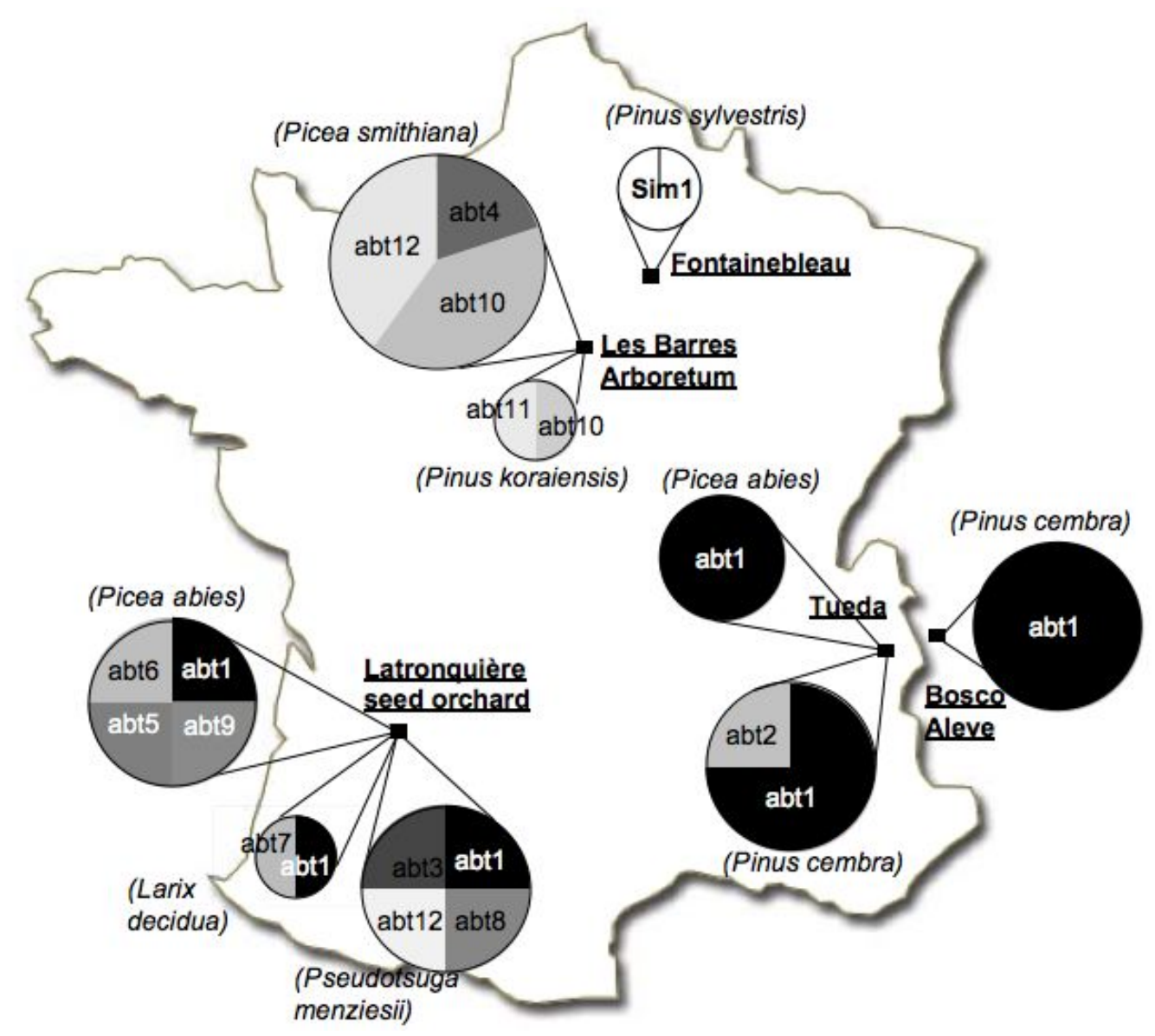



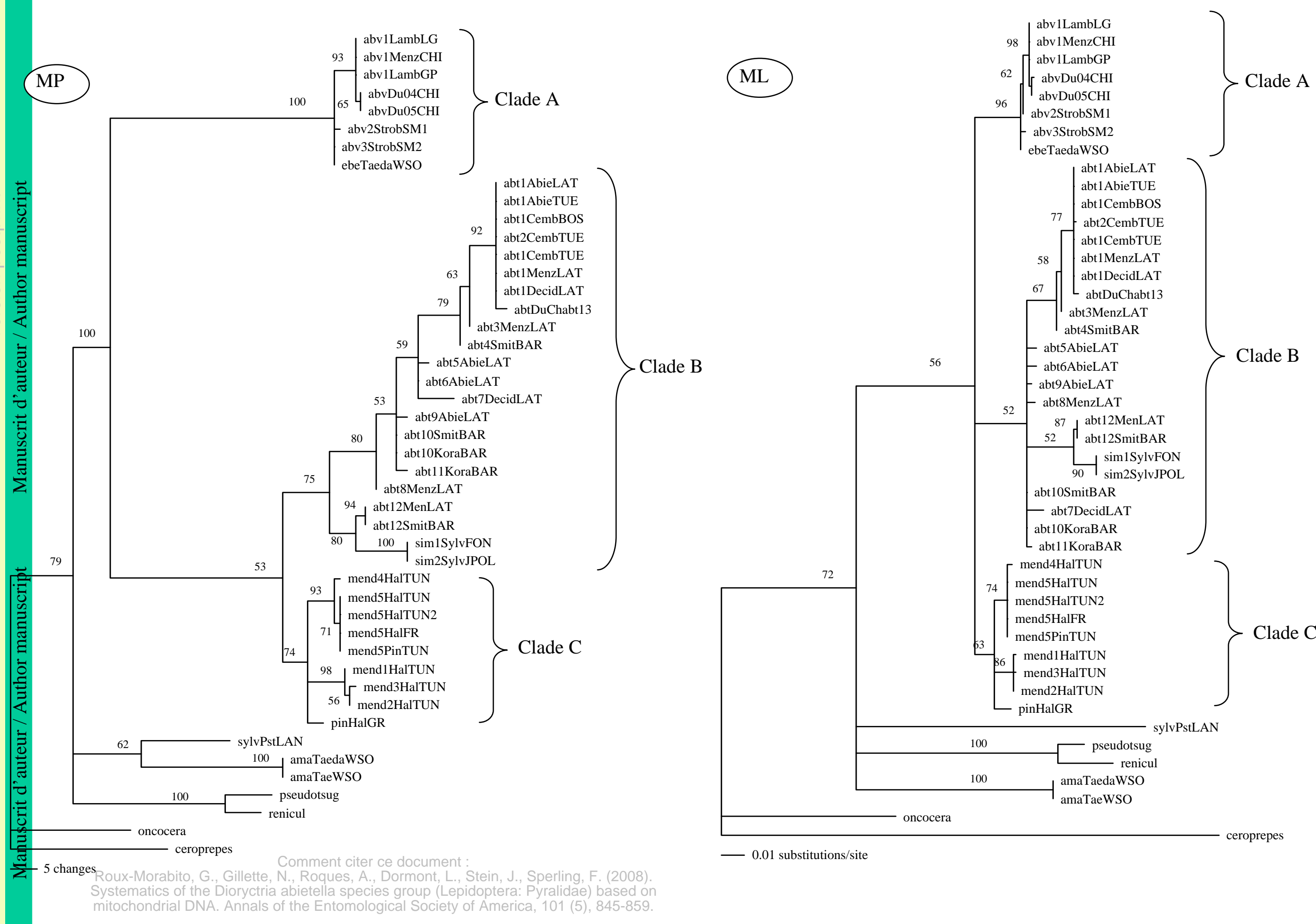

— 0.01 substitutions/site 


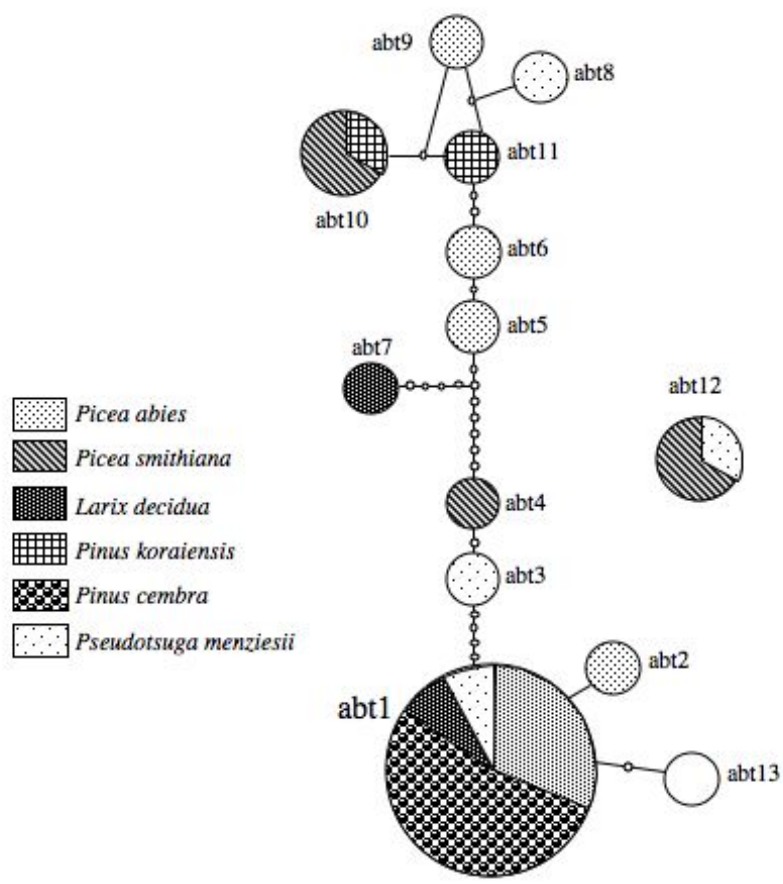

